\title{
IN-SERVICE ELEMENTARY CLASSROOM TEACHERS TRAINING IN THE PEDAGOGICAL USE OF TECHNOLOGIES IN MUSIC EDUCATION
}

\author{
Milhano $\mathrm{S}^{*}$ \\ Polytechnic of Leiria, CI \& DEI, CICS.NOVA, Portugal
}

\begin{abstract}
The importance of training in the pedagogical use of technology in the professional development of future elementary school teachers retains a special significance with the current impacts of the COVID-19 on pedagogical practices. The use of technology in primary schools is assumed in the Portuguese curricula and is part of teacher training. However, not all elementary school teachers and future teachers have the confidence and the competencies to implement it in music education classes or to embrace its use in virtual classrooms. The training underlining the professional learning of in-service elementary classroom teachers needed to be adapted to support further future teachers in creating new forms to build significant learning and teaching processes. The current paper seeks to identify in-service elementary classroom teachers learning development needs to better adapt their music education practices at school using technology. In-service elementary Portuguese teachers (16) responded to a questionnaire regarding their difficulties and training needs to better adapt their music education practices at school to online, synchronous and asynchronous strategies and activities. They suggest that some pedagogical competencies in the use of technology in their classes with children are associated with their use of technology as part of their training and most seem to have adapted to the current use of technologies in class. In-service teachers also indicate the need for further development regarding music education pedagogical topics such as strategies to promote their children music learning, learning processes assessment, and integrated approaches to the school curriculum. They expect these pedagogical topics associated with technology requirements in music education to continue as part of their current training in addition to continuous professional learning opportunities.
\end{abstract}

Keywords: music education, pedagogy, teacher training, technology

\section{Introduction}

On the sidelines of the debate between those who stand for or against technology in education and training, the truth is that, with the first closure of schools in April 2020, technology is been used on an unprecedented scale. School closure was, according to the United Nations (2020, August, p.2), the most drastic and direct consequence of the pandemia in the educational systems. Students and teachers from all levels have effectively responded to the emergency circumstances that characterized the current moment by extending their presence through the use of virtual interfaces, introducing on pedagogical practices multiple tools that allow information access and sharing as well as innovative synchronous and asynchronous communication mechanisms. On the other hand, the current student generation grew in a context of expansion and development of technologies that already characterized them by a change in their behavior and learning styles concerning previous generations. The call for disruptive and different pedagogical models in teaching and learning had already a strong call, (....). With the current 
impacts of the COVID-19 on pedagogical practices, the importance of training in the pedagogical use of technology in the professional development of future elementary school teachers retain a special significance. As an example of the importance of training in the pedagogical use of technology, the European Commission recently presented the Digital Education Plan (2021-2027) seeking to learn from the COVID-19 crisis to promote the "development of a highly effective digital education ecosystem" and the "strengthening of digital competences and skills for digital transformation" (European Commission, 2020).

The COVID-19 crisis has contributed to exposing some of teachers' weaknesses using digital technologies in education but, at the same time, has shown that technologies provide a path, a unique way, that needs to be equated not only in emergency contexts but in everyday life, providing wellstructured strategies to learn and teach. As mentioned by OECD (2020, p.11), the use of technology in teachers' professional learning was "further accelerated across the world with the COVID-19 pandemic, which has disrupted teachers' face-to-face professional learning in many education systems and created urgent needs for professional learning related to remote teaching and distance learning".

In this context, the importance of identifying in-service elementary classroom teachers professional learning needs using technology acquires major relevance to better adapt their music education practices at school. In this exploratory qualitative case study developed as part of the teacher training process, we grounded the research in the understanding of the professional learning needs of prospective teachers as learners. It was seen as a strategy to provide further conditions for their personal and professional development through the reflection on the knowledge that favors the search for answers to their real needs posed in their educational activities in classroom practice (Cavalcanti \& França-Carvalho, 2019). We grounded this study on their common characteristics and beliefs towards music education at school and the use of technologies, particularly with distance education, to integrate those into their learning experiences (Knowles, 1984) and support them in becoming more proficient to evaluate and regulate their learning.

\section{Music education in primary schools}

Music education is enshrined in the Portuguese national curriculum from an early age, since the first stage of basic education framed by the law "Lei Quadro da Educação Pré-Escolar" (Lei n. ${ }^{\circ}$ 5/97, de 10 de Fevereiro). Is part of the curriculum of the national first cycle school education in Portugal (primary school), and is involved both in the educative process and is part of the intended results. Therefore, it is possible to suggest that music education is recognized in Portugal at the institutional level as having equally a specific and a transversal contribution in a globalizing educational approach. It also has its role in promoting aesthetic and artistic sensitivity. The role of music education, as part of the arts in education curriculum, is also seen as an enhancer, but not exclusively, of the development of central competencies of problem-solving and creative thinking, considering the learning processes provided by children's participation in artistic activities (along with science) as both an instrument and objective.

Besides the presence of music education in the Portuguese curriculum, some national initiatives have been promoted to foster access to arts education in the educational community. As an example, the "Programa de Educação Estética e Artística (PEEA)", is an initiative underway for about a decade from the Direção-Geral da Educação - Ministério da Educação, based on an intervention plan which aims to implement an integrated strategy, at the national level, promoting the access to the different forms of 
art in the school context (Visual Arts, Dance, Music and Theatre). This initiative seeks to promote the arts and culture in the school universe, in partnership, whenever possible, with the different cultural institutions (museums, theatres and academies, among others). Consequently, at school, children are expected to develop certain specific competencies in the field of music, as well as to develop creativity, aesthetic sense, through contact with different universes of arts and culture. This approach presupposes progressive learning of knowledge integrated with different cultural universes, in a globalizing way. (Comissão Executiva do Plano Nacional das Artes, 2019; DGE-ME, 2019). Thus, music education tends to encourage the encounter and to value the physical presence and the direct interaction between people, in a knowledge made from the domain of different universes - educational, artistic and cultural. It encourages encounters and presupposes listening, dialoguing, creating and interpreting, clearly asking schools and their communities to learn with an emphasis on social and cultural interaction through arts and culture. Therefore, musical educational practices, in particular, include or presuppose, synergistic, collaborative, dialogic and network formats.

In this context, despite the logic of (the possible) educational continuity given the constraints caused by the COVID-19 disease (United Nations, August 2020), namely through the realization of educational, artistic and cultural activities at distance, the repetition of this scenario and the search for a balance between sustainability of on-site activities and security have, in the last year and a half, constituted a strong challenge to the development of music educational practices. For this reason, with the closure of educational and cultural spaces and, with the time restrictions and limitations in terms of the capacity of spaces to promote safety, "music emerges as one of the artistic aspects most affected by the pandemic" (Guerra, et al, 2021, p.186).

In primary school, it is emphasized the use of integrated approaches to music through children's creative engagement with other subjects' areas and different musical and artistic domains. This approach in music education values the practical music experience and children active engagement in classroom activities. Therefore, it encourages the use of a range of educational strategies that supports an integrated music education perspective (Cslovjecsek \& Zulauf, 2018), going beyond the dichotomy between 'education in music' and 'education through music'. Highlighting the opportunities put forward by an integrated approach to music education in primary school, the authors noted that this range of educational strategies presupposes a constant movement from the theoretical roots through a precise description of teaching activities to the benefits for students in terms of integration of knowledge, personal development, and social and cultural belonging. It also requires determination of didactic conditions of integrating the music education in schools and coverage of methods of arrangement of the complex relationships of the main types of educational and creative activity for students in music lessons. In this sense, it is possible to suggest that these conditions fit into the search to be an innovative teacher (Almeida, 2017) and that they may generate new teaching forms and techniques that "brings the process to a new qualitative level, enriching the musical and creative abilities of students (...) to achieve the integrity of musical and creative development and high levels of formation of aesthetic consciousness and music" (Popovych, 2014, p.748).

Regardless of music education compulsory presence in the Portuguese curriculum, there is a shared awareness that little importance is given to music education at school, reflected, for instance, in the small amount of time devoted to the subject. It is important to notice that teachers are often required to spend the majority of their time focussing on increasing their pupils' numeracy and literacy scores, and have little time left for music education and other arts subjects. As mentioned by Russel-Bowie (2009), 
this has led to some teachers developing integrated programs to cover all the required learning experiences. Thus, considering the above, the most pressing issue does not seem to lie so much in the identification of the existence and enshrinement of music education in the primary school Portuguese curriculum. Rather, it seems to reside on the creation of opportunities for its access and the promotion of its practice, with quality and equity. Therefore, as Walker mentioned (2000), the promotion of an understanding of the seminal role of music education in supporting culture as an educational force is still an issue, also in Portugal, especially in light of the "conditions of globalization" (Hebert \& Karlsen, 2010, p.10), recently marked by uncertainty (González-Alonso \& Montoya, 2021), particularly in a post-normal pandemic period.

\section{Elementary classroom teachers training in music education}

Teachers play an essential role in the learning process and in making it a fruitful experience for all students, as stressed by the European Commission/EACEA/Eurydice (2021) report on Teachers in Europe: Careers, Development and Well-being. As highlighted in the mentioned report, the pandemic, the rapid transition from face-to-face to distance learning have further highlighted teachers' essential contribution to our societies. In the context of this paper, it is important to stress elementary classroom teacher's major role in children's educational process, namely as social agents who determine the place that music and the arts have in the school culture (Tejada, et al, 2020, p.31). Unfortunately, as King noticed (2018, p.48), "due to a range of factors impacting teacher practice, not all children receive consistent and in-depth music education experiences during their primary school years". Therefore, one of the questions that arose from this, refers to elementary classroom teachers prepared to teach music and use it in their classes, particularly in light of the digital education requirements and challenges.

As some authors observed, the contributions of the musical competencies of the generalist teacher have been seen as being particularly relevant in music education at the primary school level, as well as the planning of an appropriate curriculum for their musical training (Russell-Bowie, 2009; de Vries, 2013). For instance, Bautista (2017) notes that elementary classroom teacher's initial music training is one of the factors that impact their self-efficacy perception to music teaching at primary school, in a generalist approach. Some authors also point out teachers sense of inadequacy in music teaching (Alter, et al, 2009; Hallam, et al, 2009; Holden \& Burton, 2006; Oreck, 2004; de Vries, 2013), associated with a negative attitude connected to a lack of confidence and self-efficacy towards music teaching (Garvis, 2013). As explained by Cslovjecsek (2020, p.2), "Music is a universe of its own - and making music together is a very demanding activity". But, as he also points out, "the musical competence of the teacher plays an important role, but much more decisive seems to be their pedagogical-didactic skills" (p.2).

In this line, teacher knowledge is seen as plural, heterogeneous knowledge, which is established in a specific way from varied sources and influenced by several factors (Tardif, 2002). This view questions the paradigm of technical rationality's basis of a teacher as a tool to transmit knowledge produced by others. It means that, throughout their lives, teacher knowledge is socially constructed and influenced by diverse, rich and stimulating experiences that include learning from their curriculum pathways, professional training, scientific subjects, previous school culture and life history experiences. Those experiences are unique as they contribute to whom teachers become as professionals at school, influencing the choices they make in providing high-quality teaching to each of their students. All these factors contribute to teachers process of continuously developing their plural and heterogeneous 
knowledge that is a factor for promoting significant learning experiences for all learners. These aspects are also pertinent to the music experiences they provide to their students in music education at school. Therefore, it is relevant to relate teacher knowledge in music education with those factors as a transitory and socially constructed knowledge inherent to the nature of the sense of self in the face of music. It is fundamental to recognize the existence of a "series of continuous change" along with the existence of different formative routes, opportunities, and events in music education influencing their development and achievement in different stages and fields of the music learning experience. (Milhano, 2012, 2020). Thus, managing opportunities and motivations in music education become particularly relevant in the perspective of promoting a process of continuous development and construction towards a commitment intended to last with music education and participation (Pitts, 2009).

There is an essential qualitative premise in the musical experiences provided in each moment and context, both for children and future elementary classroom teachers. The quality of these experiences can be significant both in the music education knowledge established as prospective teachers become professional's and in their formation of attitudes towards music and, thus, in the importance given to music education at school. Therefore, the conscious management of these changes in music teacher knowledge and these processes of continuous, socially constructed involvement, development and professional learning recognizes the need to follow each providing them with successful music learning experiences. The management of these also impacts the motivation levels of teachers and, therefore, generations of learners. "Successful music-making in the classroom depends not only on the skills of each individual but also very decisively on the motivation of those involved", as observed by Cslovjecsek (2020, p.2). As argued, those ideas are decisive to the process of becoming a teacher and for a professional who has the role and the power of influencing the place of music in their schools. They also impact on the choices they make in the curriculum management, in the times, spaces and pedagogical strategies they find to provide high-quality music teaching to each of their students. As mentioned by Hargreaves, Marshall \& North, (2003), the qualities of the musical interactions, situations and experiences provided to people of different ages and characteristics, influence the way each one values and uses music. In this view, the promotion of relationships between sense and meaning, in a humanizing perspective that stimulates reflection and the construction of contextualized learning and music participation pathways, acquires greater relevance (Milhano, et al, 2019; Milhano, 2021).

\section{Elementary classroom teachers professional learning in music education}

Following the meanings given by the Organisation for Economic Co-operation and Development (2020, p.15), the term "professional learning" is adopted to refer to "teachers' professionalism, highlighting the importance of teachers' own agency in contributing to defining and achieving objectives for their students, their school, the community, the system and the profession itself'. In this broad definition, formal and informal activities that "aim to update, develop and broaden the skills, knowledge, expertise and other relevant characteristics of in-service teachers" (p.14) are included.

Initial teacher education (ITE) and induction are the first steps of the continuing process of teachers' professional development (European Commission/EACEA/Eurydice, 2021a, p.8). In the Portuguese education system, elementary classroom teachers require a professional qualification structured under teacher-education profiles (EACEA, 2021b), which is obtained after having attended and passed an initial teacher training course (Educação Básica). Those courses are offered at higher education institutes and universities. Therefore, ITE programmes for elementary classroom teachers lead to 
master's degree (ISCED 7) level professional qualification according to terms laid down in the law governing teaching qualifications for teachers in pre-school, basic and upper secondary education. In these programmes, prospective teachers usually develop not only subject knowledge but also professional skills, as is the case of the participants in this study. Thus, as acknowledged by the Council of the European Union (2014), subject knowledge (such as music), and professional skills are part of the elements of elementary classroom teachers' professional development, combining subject knowledge, pedagogical theory and classroom practice. They also tend to address the five areas that foster good teaching: content, instruction, pedagogical content knowledge, knowledge of learning and development, and efficacy, as pointed out by Cavalcanti and França-Carvalho (2019).

The master's programme for the elementary classroom teachers participating in the study aims to qualify to the teaching profession, allowing them to deepen their scientific, didactic, and pedagogical knowledge related to teaching in primary schools (cf. Decreto-Lei n. ${ }^{\circ}$ 43/2007, de 22 de Fevereiro and Decreto-Lei n. ${ }^{\circ} 79 / 2014$ de 14 de Maio). It supports the consolidation of planning, assessment, reflection and critical analysis skills appropriated to diverse educational contexts, providing opportunities for the development of management practices for learning environments using differentiated pedagogy strategies. It also endeavours to provide the development of research, intervention and lifelong learning skills for future elementary classroom teachers and the development of theoretical and operational skills that allow reflection and intervention in diversified educational contexts, as complementary training to initial training.

With the pandemic crisis, teacher training was changed and equated in the face of new circumstances. In the case of the participants in the study, distance learning was used during school closure as part of their professional development, including during classroom practice in primary schools. As Burns mentioned (2011, p.3), "distance education, or distance learning, has long been a major form of professional development for pre-service and in-service teachers in developing and developed countries." The music education module syllabus developed inside academia was flexibly designed and delivered to meet learners' individual needs and to provide realistic options and choices in terms of time, place, and technology (Luschei, et al, 2008). Whenever the safety conditions allowed it, it also included on-campus, in-class, and music education practical sessions using technology and resources to increase future teachers' familiarity with technologies (Moldelki \& Giraffa, 2018) and to provide options to access and use materials in their classroom practice.

Didactic-methodological mediation processes (Prado, 2006) were supported by virtual learning environments through communication spaces in digital networks (Thompson, 2020) as well as videoconferencing, which were used to support further future teachers in creating new forms to build significant learning and teaching processes. At that point, distance teacher training in music education occurred also through the interaction between the teacher and students in the virtual space for learning and exchanging of experiences, exploring new ways of integration of the music and pedagogical interaction (Milhano, 2010). These interactions were intended to provide "the development of learning by interacting with others, aiming at searching for new possibilities of acting in the reality of the school (Prado \& Almeida, 2009). As Burns considered (2011) distance education is "not about technology, it is about people - about improving the knowledge, skills, attitudes, aptitudes, and values of teachers with the ultimate aim of improving the learning and achievement of our students of today and tomorrow" (p.272). 


\section{Methods}

This study aims to identify in-service elementary classroom teachers professional learning needs to better adapt their music education practices at school using technology. It is developed as part of the teacher training process, as a strategy to provide conditions for personal and professional development through the reflection on the knowledge that favours the search for answers to the real needs posed by in-service elementary classroom teachers in their educational action (Cavalcanti \& França-Carvalho, 2019). It is grounded on the understanding of the professional learning needs of prospective teachers as learners, there is, on their common characteristics and beliefs, to integrate those into their learning experiences (Knowles, 1984). This study is, therefore, relevant for in-service or pre-service generalists' teachers, particularly those who experience a lack of confidence in delivering music education, within distance education.

We approached this study as an exploratory qualitative case study (Yin, 2017) to gain an in-depth and critical understanding of the issue and also to provide some insights into some of the challenges of using technology in music education pedagogical practices in first cycle education schools, as part of their professional training that included observation of teaching and teaching itself. In this line, the research results cannot be extrapolated to the population under study and their interpretation must be treated in a contextualized manner.

In-service elementary Portuguese teachers (16) responded to an online questionnaire with individual accounts collected using the Moodle platform (Modular Object-Oriented Dynamic Learning Environment), in a virtual learning environment, accessible via the internet. Participants were recruited directly in the teaching syllabus, developed inside the framework of elementary classroom teacher's professional learning as part of a Portuguese master program. Participants were all female, aged between 21 and 24 years old. Written responses were received in April 2021 and provided insights, with results shared among participants.

Issues that were discussed the most across the datasets by participants were considered to be the most significant (Braun \& Clarke, 2006). Those issues were organized within categories, analysed and interpreted, and expressed through themes that illustrate respondents' views. continuity of the texts.

\section{Results and Discussion}

Results are expressed through themes that fall into three broad areas: strategies to promote children's music learning; music learning process assessment; and, integrated approaches to the school curriculum.

\section{Strategies to promote their children's music learning}

Almost all participants (15) expressed confidence regarding music content, noticing their preparation during initial training in the music subject as well as their participation in other musical activities available in their academic context (Milhano, 2021). They also expressed their preparation on technical aspects of distance learning because the training and the experience acquired previously had allowed them to develop adequate skills regarding their teaching and learning process needs within music and distance education. Thus, participants seem to feel to have adapted themselves to the current uses of technologies in music education during their classroom practices in primary schools. The use of technology along with the digital capacities needed to support planning as well as the use and 
preparation of pedagogical resources to support music teaching and learning process within distance education was not seen as a hindrance to their pedagogical practice and professional development.

In terms of technology uses, these results relate to Moldelki, Giraffa and Casatelli (2019) study that showed that teachers who already used technologies in their classes as students have a positive differential in their teaching. Nevertheless, participants expressed the need that pedagogical topics associated with technology requirements in music education to continue being part of their teacher training in addition to further continuous professional training opportunities on the subject. As showed by Atabek and Burak (2020), "having more experience in using technology or perceiving that the future profession and instructional program at the universities necessitate the use of technology improves attitude towards using technology".

Instructional variety was seen as the major development need of in-service elementary classroom teachers to better adapt their music education practices at school with technology. This necessity was mentioned by 12 of the 16 participants in the study revealing the need to develop further their knowledge on how to integrate, in music education classes, an array of assignments and activities that allow primary school children to further interact musically and to practice with musical content in multiple ways, and on multiple cognitive levels.

Alluding to Luschei, Dimyati and Padmo (2008) concept of "flexible delivery", participants expressed the need to deepen their knowledge on activities based on musical practice that better meet children's individual musical needs and interests. Instrumental music activities were particularly indicated, spacially group musical practice, as they considered that children tend to associated music education with instrumental practice, as observed by Milhano (2012). As noticed by Vilassol (2017), teachers need to be open and connected with innovation through theories and practice of doing, searching for new ways that involve de learning process of their pupils.

In line with the above, it is possible to suggest that in-service elementary classroom teachers participating in the study already used technologies from a positive perspective. Nonetheless, data indicate that these future teachers are still in the process of aligning with the skills and resources needed to support both music teaching and its learning process within distance education. As noted by Almeida (2017), these prospective teachers may fit into the role of the instrumental teacher, needing to go a long way in the educational process in the search to be an innovative teacher.

\section{Music learning process assessment}

Assessing children's music learning process at distance, using technologies was also expressed as a major challenge for participants (12), not only because it plays a significant role in the guidance of the educational process but also as it is seen as difficult to endeavour "valid" and "realistic" children's individual and group musical performance-based assessments. As explained by Luckesi (2005), assessment is a process that is related to the management of student learning since it contributes to the organization of schoolwork and the regulation and restructuring of teaching. Assessment refers to any of a variety of procedures, using multiple measures and methods to assess learning. The information obtained is helpful by supporting the student through the confirmation of the realization of learning and, at the same time, by offering a work orientation for the teacher. 
In the music learning process, participants particularly highlighted the challenges inherent to the collection of information, through a contextualized and reciprocal action, that supports the assessment of the musical creative process developed by children. The performative nature of music, the synergistic, collaborative, dialogic and network formats of music education along with the processes of distance teaching that physically separated, in space, and sometimes in time, in-service classroom teachers from their pupils, were seen as a specific challenge in their classroom practices in primary schools. As noted by Popovych $(2014$, p. 751$)$, the dialectical nature of the learning process, implies commitment and consistency of teaching as well as the creation of space for music and children's creative work. Although participants have acknowledged that digital technologies may overcome this lack of physical contact (Cavalcanti \& França-Carvalho, 2019), they indicated the need to further deepen procedures and technics related to the assessment of music performance in the domain of music creativity. As noted by Kim (2013, p. 3), quoting Prensky (2001) "the introduction of technologies in music classes is often taken for granted because the students of today are "digital natives".

Thus, data suggest that, for one hand, the assessment of pupils learning process in the domain of music creativity is particularly challenging for in-service elementary classroom teachers participating in the study due to the performative nature of music, reinforced by the requirements of the need for more profound technical audio, video, and online media skills that allow them to engender and improve their use of a variety of pedagogical approaches in assessment. Also, there's a suggestion for further training and practice for the development of "skills" or "procedural knowledge", such as processes, measures and methods to more adequately and confidently assess their pupils' music learning processes.

\section{Integrated approaches to the school curriculum}

Participants expressed the need to deepen their knowledge on integrated music education approaches and continuing exercising integrated ways of approaching the curriculum. As mentioned by Cslovjecsek (2020), there is a range of educational strategies that may benefit students in terms of integration of knowledge, personal development, and social and cultural belonging. Popovych (2014) highlights the complexity of planning and implementing an integrated approach in music education, noticing that the "simultaneous use of different kinds of musical activities can be considered as one of the priority choices of a complex structure of the music lesson" (p. 754). However, the same author stressed that "engaging students in music and creative activities within an integrated approach creates a positive training motivation and leads to increased creativity, activity and autonomy in artistic and creative tasks" (p. 754). This issue is of particular relevance due to the transversal contribution that music education can have in a globalizing educational approach and, consequently, in music teachers training as generalist teachers in primary school settings. The context experience and experimenting with different teaching practices to support student learning required participants to become more aware of their pupils' needs as well as their own.

This issue also emerged, for some participants (5), associated with the lack of time they mentioned having to implement music education at primary school. These perceptions contribute to reinforce the shared awareness that little importance is given to music education at school, besides its compulsory presence in the Portuguese curriculum. Thus, data suggest that integrated music education approaches may be seen by participants as a way to create more opportunities for the promotion of music education practices in primary school as supporting its educational force (Walker, 2000). 


\section{Conclusions}

With the current impacts of the COVID-19 on pedagogical practices, the opportunities and settings of the professional learning of future elementary school teachers needed to be adapted. Distance learning was used during school closure as part of their professional master degree programme, including during music education classroom practice in primary schools. The current exploratory case study was developed as part of the teacher training process and approached as a formative strategy to provide conditions for the participants personal and professional learning. It aimed to identify these prospective teachers professional learning needs to better adapt their music education practices at school using technology. This study is relevant for in-service or generalists' teachers, particularly those who experience a lack of confidence in delivering music education, within distance education. As acknowledged, teaching involves an extraordinarily complex set of practices and the process of developing good generalist music education teachers is not simple. It involves a continuous process with inputs from varied sources and is influenced by several factors.

The process of reflection on knowledge undertook by in-service elementary classroom teachers and their evaluation and search for answers to their own real needs provided support and regulation for their learning and professional development. This strategy was envisioned to promote the development of new reflections on education, to encourage the realization and sharing of new learning and teaching experiences. It was also aimed to improve music teaching practice and children's learning.

According to the results presented, it is possible to suggest that, although in-service elementary classroom teachers participating in the study showed positive attitudes, disposition and some degree of confidence towards music teaching at school using technology, they are still in the process of aligning with the skills and resources needed to support both music teaching and its learning process, within distance education. Their perceived professional learning, needs seems to be mainly associated with the broadening of a range of "skills" or "procedural knowledge", linked to an instructional variety that includes processes, procedures, and strategies to better promote their children's musical learning with distance music education being one of the parts of their improvement process.

\section{Acknowledgements}

This work is funded by National Funds through the FCT - Foundation for Science and Technology, I.P., within the scope of the project $\operatorname{Ref}^{a}$ UIDB/05507/2020. Furthermore, we would like to thank the Centre for Studies in Education and Innovation (CI\&DEI) and the Polytechnic of Leiria for their support.

\section{Declaration of Interest Statement}

The author declare that they have no conflicts of interests.

\section{References}

Almeida, P. (2017) Tecnologias digitais em sala de aula: O Professor e a reconfiguração do processo educativo. Revista da Investigação às Práticas, 8(1), 4-21. 
Alter, F., Hays, T., \& O'Hara, R. (2009). Creative arts teaching and practice: critical reflections of primary school teachers in Australia. International Journal of Education and the Arts, 10(9), 1-21.

Atabek, O., \& Burak, S. (2020). Pre-school and primary school pre-service teachers' attitudes towards using technology in music education. Eurasian Journal of Educational Research (EJER), 47-68. https://doi: 10.14689/ejer.2020.87.3.

Bautista, P. (2017). El futuro maestro generalista ¿preparado para utilizar la música en su enseñanza? Educación y Ciencia, 6(47), 32-44.

Braun, V., \& Clarke, V. (2006). Using thematic analysis in psychology. Qualitative Research in Psychology, 3, 77-101. https://doi:10.1191/1478088706qp063oa.

Burns, M. (2011). Distance Education for Teacher Training: Modes, Models and Methods. Education Development Center. Retrieved from https://www.edc.org/sites/default/files/uploads/DistanceEducation-Teacher-Training.pdf

Cavalcanti, Á., \& França-Carvalho, A. D. (2019). Teacher Training and Pedagogical Assistance in Distance Education. International Journal of Advanced Engineering Research and Science, 6, 160-166. https://doi:10.22161/ijaers.68.20

Comissão Executiva do Plano Nacional das Artes (2019). Plano Nacional das Artes. Uma estratégia, um manifesto 2019-2024. Retrieved from https://www.dge.mec.pt/sites/default/files/Projetos/PNA/Documentos/estrategia_do_plano_nacional_ das_artes_2019-2024.pdf

Council of the European Union (2014). Council conclusions of 20 May 2014 on effective teacher education, OJ C 183, 14.6.2014. Retrieved from https://eur-lex.europa.eu/legalcontent/EN/TXT/PDF/?uri=CELEX:52014XG0614(05)\&from=EN

Cslovjecsek, M., \& Zulauf, M. (Eds.). (2018). Integrated Music Education. Bern, Switzerland: Peter Lang CH. Retrieved from https://www.peterlang.com/view/title/34993

Cslovjecsek, M. (2020). Development-oriented learning approaches and the demand for an integrated understanding of teaching: A plea for more music in school. Didacticae, 7, 1-3. https://doi: 10.1344/did.2020.7.1-3

Direção-Geral da Educação - Ministério da Educação (2019). Estratégia do Plano Nacional das Artes. Retrieved from https://www.dge.mec.pt/sites/default/files/Projetos/PNA/Documentos/estrategia_do_plano_nacional_ das_artes_2019-2024.pdf

European Commision (2020). Plano de Ação para a Educação Digital (2021-2027) Reconfigurar a educação $e$ a formação para a era digital. Retrieved from https://ec.europa.eu/education/sites/default/files/document-library-docs/deap-communicationsept2020_en.pdf

European Commission/EACEA/Eurydice (2021a). Teachers in Europe: Careers, Development and Well-being. Eurydice report. Luxembourg: Publications Office of the European Union. Retrieved from https://eacea.ec.europa.eu/nationalpolicies/eurydice/sites/default/files/teachers_in_europe_2020_chapter_2_0.pdf

European Commission/EACEA/Eurydice (2021b). Portugal. Teachers and Education Staff. Retrieved from https://eacea.ec.europa.eu/national-policies/eurydice/content/teachers-and-education-staff-59_en Garvis, S. (2013). Beginning generalist teacher self-efficacy for music compared with maths and English. British Journal of Music Education, 30(1), 85-101. https://doi: 10.1017/S0265051712000411 
González-Alonso, F., \& Montoya, F. S. (2021). Interrupción del aprendizaje por covid-19: dificultades, oportunidades e incertidumbres. In Pesántez-Avilés, F., Álvarez-Rodas, L., \& Torres-Toukoumidi, A. (Org). COVIDA-20 Una coalición educativa para enfrentar la pandemia. Pearson, 41-54.

Guerra, P., Oliveira, A., \& Sousa, S. (2021). Um Requiem pelas músicas que perdemos: percursos com paragens pelos impactos da pandemia na produção musical independente em Portugal. $O$ Público e $O$ Privado, 38, 171-198. Retrieved from https://repositorioaberto.up.pt/bitstream/10216/133589/2/462780.pdf

Hallam, S., Burnard, P., Robertson, A., Saleh, C., Davies, V., Rogers, L., \& Kokatsaki, D. (2009). Trainee primary-school teachers' perceptions of their effectiveness in teaching music. Music Education Research, 11(2), 221-240. https://doi: /10.1080/14613800902924508

Hargreaves, D. J., Marshall, N., \& North, A. (2003). Music education in the twenty-first century: a psychological perspective. British Journal of Music Education, 20(02). doi.org/10.1017/S0265051703005357

Hebert, D., \& Karlsen, S. (2010). Editorial introduction: Multiculturalism and music education. Musiikkikasvatus The Finnish Journal of Music Education (FJME), 13(1).

Holden, H., \& Button, S. (2006). The teaching of music in the primary school by the non-music specialist. British Journal of Music Education, 23(1), 23-38. https://doi:10.1017/S0265051705006728

Kim, E. (2013). Music technology-mediated teaching and learning approach for music education: A case study from an elementary school in South Korea. International Journal of Music Education, 31(4), 413-427. https://doi.org/10.1177/0255761413493369

King, F. (2018). Music Activities Delivered by Primary School Generalist Teachers in Victoria: Informing Teaching Practice. Australian Journal of Teacher Education, 43(5), 175-186. https://doi.org/10.14221/ajte.2018v43n5.4. Retrieved from

Knowles, M. S. (Ed.). (1984). Andragogy in action. San Francisco. CA: Jossey-Bass.

Oreck, B. (2004). The artistic and professional development of teachers' study of teachers' attitudes toward and use of the arts in teaching. Journal of Teacher Education, 55, 55-69. https://doi:10.1177/0022487103260072

Luckesi, C. C. (2005). Avaliação da aprendizagem escolar: estudos e proposições (17nd ed). São Paulo: Cortez.

Luschei, T. F., Dimyati, S., \& Padmo, D. (2008). Maintaining e3-learning while transitioning to online instruction: The case of the Open University of Indonesia. Distance Education, 29(2), 165-174. https://doi:10.1080/01587910802154962

Milhano, S. (2010). Aprendizagem assistida - da inovação tecnológica aos novos modos de integração da interacção pedagógica. Revista Portuguesa de Educação Musical, 134, 35-41.

Milhano, S. (2012). Primary school children's opportunities and motivations in music: a research in different contexts of music education, EDULEARN12 International Association for Technology, Education and Development, 6591-6600.

Milhano, S., Sousa, J., \& Lopes, S. (2019). Primary Pupil's Perceptions of their Participation in a Performative Music Project - Crianças ao Palco. The Future of Education Conference Proceedings 2019, 215-234. Retrieved from https://conference.pixel-online.net/FOE/files/foe/ed0009/FP/5818MUS3980-FP-FOE9.pdf

Milhano, S. (2020). Exploring Formative Routes, Opportunities, and Events in Music Education. The Future of Education Conference Proceedings 2020, 4594-4619. Retrieved from https://conference.pixel-online.net/FOE/files/foe/ed0010/FP/5818-ART4594-FP-FOE10.pdf 
Milhano, S. (2021). Fostering Meaningful and Creative Connections in Higher Education: Contributions from Music Education. European Scientific Journal, ESJ, 17(26), 27. https://doi.org/10.19044/esj.2021.v17n26p27

Moldelki, D., \& Giraffa, L. M. M. (2018). Formação Docente Práticas Pedagógicas e Tecnologias Digitais: Reflexões ainda necessárias. Revista Eletrônica PESUISEDUCA, 10 (20), 116-133. Retrieved from https://periodicos.unisantos.br/pesquiseduca/article/view/678/pdf

Organization for Economic Co-operation and Development (2020). Policies to support teachers' continuing professional learning: a conceptual framework and mapping of OECD data. Education $\begin{array}{lllll}\text { Working } & \text { Paper } & \text { No. } & \text { Retrieved }\end{array}$ https://www.oecd.org/officialdocuments/publicdisplaydocumentpdf/?cote=EDU/WKP(2020)23\&doc Language $=$ En

Pitts, S. (2009). Roots and routes in adult musical participation: investigating the impact of home and school on lifelong musical interest and involvement. British Journal of Music Education, 26(3), 241256.

Popovych, N. (2014). The Role of an Integrated Approach in Music Education Technology. European Researcher, (73), 4-2, 748-755. https://doi: 10.13187/issn.2219-8229

Portugal. Lei Quadro da Educação Pré-Escolar, Lei n. ${ }^{\circ}$ 5/97, de 10 de Fevereiro

Portugal. Decreto-Lei $n .^{\circ} 43 / 2007$, de 22 de Fevereiro

Portugal. Decreto-Lei $n .^{\circ} 79 / 2014$, de 14 de maio

Prado, M. E. B.B. (2006). A Mediação Pedagógica: suas relações e interdependências. Simpósio Brasileiro de Informática na Educação - SBIE Anais, 101-110. Retrieved from http://www.br-ie.org/p ub/index.p hp /sbie/ article/viewFile/470/456.

Prado, M. E. B.B., \& Almeida, M. E. B. (2009). Formação de educadores: fundamentos reflexivos para o contexto da educação a distância. In: Valente, J. A., Bustamante, S. B. V. (org.). Educação a distância: prática e formação do profissional reflexivo, 65-82.

Russell-Bowie, D. (2009). Syntegration or disintegration? Models of integrating the arts across the primary curriculum. International Journal of Education \& the Arts, 10(28).

Tardif, M. (2002). Saberes docentes e formação profissional. Petrópolis, RJ: Vozes.

Tejada, J., Thayer, T., \& Arenas, M. (2020). In-service music teaching performance of Chilean generalist teachers. A mixed-methods exploratory study. Didacticae, 7, 30-56. https://doi:10.1344/did.2020.7.30-56.

Thompson, K. P. (2020). Media, music, and adolescents. Early Adolescence. Routledge, 407-418.

United Nations (August 2020). Policy brief: education during covid-19 and beyond. Retrieved from https://www.un.org/development/desa/dspd/wp-

content/uploads/sites/22/2020/08/sg_policy_brief_covid-19_and_education_august_2020.pdf

Vilassol, M. C. (2017). Aprendizagem baseada em projeto de ensino: aprendizagem, criatividade, inovação e novos papéis na formação de professores na era digital. Journal of Applied and Advanced Research, 29(4), 1253-1278.

de Vries, P. (2013). Generalist teachers' self-efficacy in primary school music teaching. Music Education Research, 15(4), 375-391. https://doi: 10.1080/14613808.2013.829427

Walker, R. (2000). Multiculturalism and Music Re-Attached to Music Education. Philosophy of Music Education Review, 8(1), 31-39.

Yin, R. (2017). Case Study Research and Applications: Design and Methods. SAGE. 